\title{
Kinerja Reproduksi Sapi Potong Induk pada Kondisi Petemakan Rakyat di Lahan Majinal Desa Srigonco Kabupaten Malang, Jawa Timur
}

\section{(Reproductive Performance of Beef Cows at Small Fammer Scale of Marginal Land Srigonco Village in Malang District, EastJ ava)}

\author{
Dikman DM, Ratnawati D, Affandhy A \\ Loka Penelitian Sapi Potong \\ Jl. Pahlawan Grati 02 Kabupaten Pasuruan 67184 Provinsi Jawa Timur, Indonesia \\ dickydikman@gmail.com
}

\begin{abstract}
The research was carried out for 4 years (2010-2013) aimed to improve the reproductive performance of cows through improved feed for two months before and after calving. There were 141 heads owned by farmers; 3-4 years old. Rice straw or corn stover were given ad libitum during the study, with additional supplements of legumes approximately $0.5 \% \mathrm{DM}$ of body weight (BW). Two months before and after calving, more supplemental feed were given approximately 1.0\% DM of BW. The daily gain in 2010, 2011, 2012 and 2013 decreased respectively $-0.05 \pm 0.03 \mathrm{~kg} / \mathrm{day},-0.03 \pm 0.03 \mathrm{~kg} /$ day, $-0.22 \pm 0.21 \mathrm{~kg} /$ day and $-0.13 \pm 0.17 \mathrm{~kg} / \mathrm{day}$, body condition score decreased up to 19.35\% (in 2010) and 15.63\% (in 2011 and 2012); but in 2013 decreased up to -5, anestrus post partus (APP) and service per conception (S/C) in 2013 were the highest. APP in 2013 was the highest caused by longer affected the S/C and conception rate impactingon calving interval. The calving interval showed a decrease in three years of 2010-2012 which were $532.8 \pm 174.0$ days, $533.5 \pm 178.3$ days in 2011 , and $486.0 \pm 69.7$ days, respectively in 2012.
\end{abstract}

Key words: Reproductive performance, beef cows, small farmer

\begin{abstract}
ABSTRAK
Peningkatan kinerja reproduski sapi induk kondisi peternakan rakyat bisa berdampak terhadap perpendekan calving interval dan jumlah kelahiran induk setiap tahun diperlukan untuk mendukung progam swasembada daging nasional. Peneltian ini bertujuan untuk meningkatkan kinerja reproduksi sapi potong induk melalui perbaikan pakan induk selama dua bulan sebelum dean sesudah beranak. Kegiatan penelitian dilaksanakan selama 4 (empat) tahun (tahun 2010-2013). Materi penelitian menggunakan sapi-sapi induk PO milik petani berjumlah > 100 ekor sapi induk dan turunannya; dengan umur sapi 3-4 tahun. Sapi induk akan mendapatkan pakan berupa jerami padi atau jagung secara ad.libitum selama periode penelitian, dengan tambahan suplemen berupa leguminosa sekitar 0,5\% berdasar bahan kering (BK) pakan dari bobot badan. Dua bulan sebelum melahirkan dan dua bulan setelah melahirkan sapi induk akan mendapatkan pakan suplemen yang lebih yaitu 1,0\% BK bobot badan induk untuk memenuhi peningkatan kebutuhan energi. Performa produksi dan reproduksi sapi-sapi induk menunjukkan bahwa PBBH sapi induk laktasi pada tahun 2010, 2011, 2012 dan 2013 mengalami penurunan masing-masing adalah -0,05 $\pm 0,03 \mathrm{~kg} / \mathrm{hari}$, $-0,03 \pm 0,03 \mathrm{~kg} / \mathrm{hari},-0,22 \pm 0,21 \mathrm{~kg} / \mathrm{hari}$ dan $-0,13 \pm 0,17 \mathrm{~kg} / \mathrm{hari}$, demikian juga SKT sapi induk laktasi penurunan hingga 19,35\% (tahun 2010) dan 15,63\% (tahun 2011 dan 2012); tetapi pada tahun 2013 terjadi penurunan SKT hingga -5, sehingga nilai APP dan S/C pada 2013 lebih besar dibandingkan dengan tahun sebelumnya. APP pada tahun 2013 menjadi paling
\end{abstract}


tinggi dibandingkan dengan tahun 2012, 2011 dan 2010. Tingginya APP pada tahun 2013 akibat waktu penyapihan pada tahun tahun 2013 lebih panjang daripada tahun 2010, 2011 dan 2012; sehingga menyebabkan APP sapi-sapi laktasi menunjukkan nilai tinggi yang akan berpengaruh terhadap S/C dan CR dan berdampak terhadap jarak beranak. Disimpulkan bahwa jarak beranak induk di wilayah Malang menunjukkan penurunan dalam kurun waktu 3 tahun penelitian, yaitu 532,8 $\pm 174,0$ hari pada tahun 2010 dan 533,5 $\pm 178,3$ hari pada tahun 2011, dan 486,0 $\pm 69,7$ hari pada tahun 2012.

Kata kunci: Performa reproduksi, sapi potong induk, peternakan rakyat

\section{PENDAHULUAN}

Salah satu strategi pemerintah untuk mencapai swasembada daging dan peningkatan populasi sapi hingga pada tahun 2019 dapat dilakukan dengan cara memperbaiki sumber genetik sapi-sapi lokal Indonesia, seperti sapi Bali (Bos sondaicus), sapi PO dan Sapi Madura ataupun hasil silangannya seperti sapi Jabress di Brebes, sapi-sapi PO Kebumen di Kab. Kebumen ataupun bila terpaksa melalui impor sapi melalui sistem kredit KUPS (Kredit Usaha Pembibitan Sapi) pada era tahun 2013 seperti pada Bhrhman corss. Pertimbangan pemilihan Brahman diantaranya adalah tingkat pertumbuhan yang lebih cepat dan rasio konversi pakan yang lebih tinggi daripada sapi lokal. Kesuksesan program Brahman pada peternakan rakyat masih diragukan. Beberapa perusahaan menyatakan bahwa Brahman menguntungkan, namun pada peternak kecil belum dapat melihat investasi mereka kembali. Permasalahan utama yang terjadi adalah kemampuan reproduksi induk setelah beranak yang rendah, tingkat kematian pedet yang tinggi dan pertumbuhan sapi muda yang rendah. Permasalahan tersebut terkait dengan kecukupan nutrisi yang kurang serta manajemen perkawinan dan penyapihan yang belum maksimal.

Kebutuhan daging nasional sebesar 1,7 kg/kapita/tahun atau setara dengan 1,75-2,0 juta ekor sapi masih harus dipenuhi dengan impor sebesar 30\% (Noor 2008). Hal ini dikarenakan populasi ternak sapi potong dalam negeri masih belum cukup untuk memenuhi kebutuhan daging nasional. Sumaryadi (2008) menyatakan bahwa untuk memenuhi kebutuhan daging nasional masih diperlukan impor daging dan ternak potong bakalan. Rendahnya populasi ternak potong dalam negeri disebabkan oleh rendahnya reproduktivitas induk dengan berbagai permasalahannya antara lain: kawin berulang, angka kebuntingan yang rendah dan panjangnya calving interval. Demikian pula sebagian besar pelaku usaha penggemukan sapi potong dijalankan oleh para peternak rakyat yang menyebar di seluruh wilayah Indonesia khusunya di wilayah Propinsi Jawa Timur. Usaha penggemukan sapi potong skala peternakan rakyat ini belum mampu meningkatkan kesejahteraan para peternaknya khusunya dari segi ekonomi. Hal tersebut terkait dengan tingkat manajemen pemeliharaan, pengadopsian teknologi dan bahkan ketersediaan dan kemudahan mendapatkan bahan pakan yang masih rendah. Oleh karena itu, peningkatan produktivitas dan profitabilitas usaha pembibitan sapi potong skala peternakan rakyat perlu diimbangi dengan teknologi perbaikan tatalaksana pakan yang mengedepankan pengembangan pakan terbaik dengan parameter kunci kandungan dan konsumsi energi metabolis serta protein pakan minimum guna memaksimalkan pertambahan bobot badan ternak. Pengembangan pakan terbaik (best bet feeding) diharapkan mampu memanfaatkan berbagai sumber pakan yang telah tersedia di lingkungan peternak untuk diformulasikan sedemikian rupa sehingga dapat membantu peternak rakyat untuk meningkatkan nilai PBBH sekaligus memperpendek periode pemeliharaan ternak dan secara otomatis dapat meningkatkan kesejahteraan perekonomiannya. Kegiatan penelitian ini akan dilaksanakan 
karena belum adanya ketersediaan informasi yang dipublikasikan tentang bagaimana tampilan bangsa ternak yang berbeda di bawah kondisi pemeliharaan di desa dengan adanya penerapan formulasi pengembangan pakan terbaik (best bet feeding).

Hasil peneltian sebelumnya juga menunjukkan bahwa dengan melakukan perbaikan skor kondisi tubuh ternak pada saat kebuntingan tua menjadi skor kondisi tubuh $>2,5-5$ (skala 1-5) dapat memperbaiki kondisi tanda berahi sapi PO induk pasca beranak dengan cara memberikan tambahan pakan berupa legum pakan hijauan ataupun konsentrat di tingkat peternak di Kab. Malang (Dikman et al. 2011) dan Affandhy et al. (2011) melaporkan pada awal penelitian diperoleh rata-rata skor kondisi tubuh sapi induk di kab. Probolinggo sebesar 2,7 dan di kab. Malang sebesar 3,1 (skala 1-5), namun Anestrus Post Partus di kab. Probolinggo tampak lebih rendah daripada di Wilayah Malang dengan rataan umur penyapihan pedet di Probolinggo dan Malang masing-masing adalah 110 dan 166 hari.

Penelitian ini bertujuan untuk mendeteksi capaian kinerja reproduksi sapi potong induk pada kondisi peternakan rakyat dengan sistem pemeliharaan dua bulan sebelum dan sesudah bernak mendapat perbaikan pakan.

\section{MATERI DAN METODE}

Penelitian dilaksanakan di Desa Srigonco Kec. Bantur Kab. Malang, Provinsi Jawa Timur. Kriteria wilayah adalah dataran sedang 200-400 m dengan kondisi agroekosistem tanah kering berbukit ( $>60 \%$ lahan tegalna) dengan pakan berbasis jerami padi/jagung dan leguminosa (gamal dan lamtoro).

Kegiatan ini dilaksanakan mulai tahun 2010 sampai dengan 2013 dengan materi penelitian menggunakan sapi-sapi induk PO milik petani berjumlah > 100 ekor sapi induk dan turunannya. Setiap sapi induk diberikan nomor identitas (ID) sebanyak 7 digit yang dikalungkan pada sapi dengan kreteria, 3-4 tahun kelahiran dan 5-7 nomor acak dalam satu tahun. Bila ada pedet yang lahir dari induk responden dan pejantan yang digunakan untuk mengawini sapi induk akan diberikan nomor ID juga. Sapi induk akan mendapatkan pakan berupa jerami padi atau jagung secara ad libitum selama periode penelitian. Jika kebutuhan pakan untuk menopang hidup pokok rendah, sapi-sapi induk akan mendapatkan sedikit tambahan suplemen yang berkualitas tinggi sekitar 0,5\% berdasar bahan kering (BK) pakan dari bobot badan. Dua bulan sebelum melahirkan dan dua bulan setelah melahirkan sapi induk akan mendapatkan pakan suplemen yang lebih yaitu 1,0\% BK bobot badan induk untuk memenuhi peningkatan kebutuhan energi.

Semua sapi induk akan diberikan jerami padi secara ad libitum (sebanyakbanyaknya sapi dapat mengkonsumsinya) selama kegiatan penelitian berlangsung. Jika jerami padi tidak tersedia, jerami jagung dapat diberikan. Diperkirakan bahwa sapi-sapi induk dapat mengkonsumsi jerami padi sekitar 2,5\% dari bobot badannya per hari. Jerami padi dapat diberikan dalam bentuk segar saat habis panen, sedangkan diberikan dalam bentuk kering bahan keringnya mencapai 80\%. Pakan suplemen yang digunakan berupa legum pohon (daun gamal, turi, lamtoro dan kelor), limbah industri pertanian (dedak padi, jerami kacang tanah), limbah industri makanan (ampas tahu, tepung gaplek, tepung kedelai, dan lain-lain). Konsumsi pakan dan air minum dicatat sekali dalam sebulan sebanyak 25\% dari sapi responden.

Perkawinan sapi induk milik rakyat sesuai dengan keinginan peternak yaitu pertama menggunakan inseminasi buatan dan apabila tidak terjadi kebuntingan menggunakan pejantan sapi PO yang sudah disediakan pada masing-masing lokasi dan kedua langsung menggunakan pejantan sapi PO bagi peternak yang ingin memperoleh keturunan pedet 
sapi PO dengan cara membawa sapi induk ke tempat lokasi pejantan. Penyapihan pedet diharapkan pada umur 4-6 bulan dengan cara diberi sekat atau dijauhkan dari induknya dengan dibatasi ternak lainnya agar pedet tidak dapat melihat atau mendengar induknya guna mempercepat berahi induknya.

Data yang diperoleh dari kegiatan penelitian dianalisis secara deskriptif; dengan beberapa variabel dan parameter, yaitu:

a) Informasi pendaftaran ternak/Enrollment (Tahun kelahiran, banyaknya beranak, umur pedet yang sedang disusui, status kebuntingan, perkiraan tanggal kelahiran, status laktasi, tipe perkandangan dan ternak digunakan untuk membajak).

b) Silsilah ternak (Jenis kelamin, bangsa, tahun lahir, bulan lahir, tanggal lahir, berat lahir, tanggal penyapihan, berat sapih, ciri-ciri khusus, konformasi tubuh 1 s.d. 5 dimana 1 adalah nilai terrendah dan 5 nilai tertinggi, tanggal kematian dan penyebab kematian).

c) Data regular, yaitu status pemilikan ternak (pemilik atau penggaduh), status kebuntingan (kosong/tidak bunting, umur kebuntingan), status laktasi (laktasi atau kering), bobot badan, lingkar dada, tinggi gumba, panjang badan dan skor kondisi tubuh. Pengukuran data regular dilakukan setiap bulan sekali.

d) Data reproduksi (Tanggal berahi pertama kali, tanggal kawin, tipe perkawinan (alam atau IB) dan nomor identitas pejantan atau kode straw.

e) Data hasil perkawinan (Nomor identitas pedet, jenis kelamin pedet, tanggal lahir, berat lahir, nomor identitas asal induknya dan pejantannya, berat sapih, nasib pedet (mati, dijual dan berhasil disapih).

f) Data lain berupa kesehatan ternak (obat, dosis, jenis penyakit, biaya pengobatan dan biaya pelayanan), nilai ternak (tanggal penjualan, berat dan SKT saat dijual, siapa yang menentukan dijual, pembeli, harga jual/beli, pemanfaatan uang hasil penjualan sapi dan alasan menjual sapi.

g) Data iklim (Curah hujan, suhu maksimum dan minimum, dan kelembaban udara).

\section{HASIL DAN PEMBAHASAN}

\section{Perkawinan sapi induk}

Tabel 1. Pengelolaan perkawinan sapi induk di wilayah Malang pada tahun 2010, 2011, 2012 dan 2013

\begin{tabular}{lcccc}
\hline \hline \multirow{2}{*}{ Parameter } & \multicolumn{4}{c}{ Tahun } \\
\cline { 2 - 5 } & 2010 & 2011 & 2012 & 2013 \\
\hline Perkawinan IB (\%) & 92,0 & 92,0 & 91,0 & 100,0 \\
Perkawinan alam (\%) & 8,0 & 8,0 & 9,0 & 0 \\
Waktu penyapihan pedet (hari) & $166,5 \pm 30,5$ & $160,2 \pm 36,5$ & $163,6 \pm 13,9$ & $181,8 \pm 20,8$ \\
Kawin hari ke-1 estrus (\%) & 77,0 & 78,0 & 69,0 & 84,0 \\
kebuntingan pada estrus ke-1 & 58,0 & 58,0 & 46,0 & 40,0 \\
$\begin{array}{l}\text { (\%) } \\
\text { Kebuntingan pada kawin ke-1 }\end{array}$ & 50,0 & 57,0 & 63,0 & 62,0 \\
$\begin{array}{l}\text { I) } \\
\text { Induk estrus ketika laktasi(\%) }\end{array}$ & 36,0 & 53,0 & 44,0 & 27,0 \\
\hline
\end{tabular}


Pola perkawinan sapi induk antara sapi IB sejak tahun 2010 hingga tahun 2013 meningkat hingga 100\% dibandingkan perkawinan menggunakan sapi pejantan semakin menurun; dengan waktu penyapihan pedet lebih lima bulan (Tabel 1). Akibatnya peternak penyapihan pedet yang terlalu panjang dengan alasan menunggu pemisahan pedet akibatnya perkawinan sapinya bisa $>120$ hari dan berdampak terhadap jarak bernak sapi (Affandhy et al. 2019).

Walaupun lama laktasi dan APP semakin lama (Tabel 2); dengan adanya program anjuran untuk melakukan perkawinan sapi induk pada estrus pertama kali hingga 84\% akan menyebabkan menaikkan tingkat kebuntingan sapi hingga 62\% (Tabel 1). Dengan demikian faktor pengelolaan reproduksi terutama waktu kawin yang tepat yang disertai dengan menjaga kondisi induk akan memperbaiki efisensi reproduksi induk terutama pada saat bunting tua dan pasca beranak. Di wilayah Malang merupakan wilayah yang berbukit sehingga perkawinan IB agak terhambat. Tingkat kebuntingan juga dipengaruhi oleh faktor nutrisi dan body condition (Boothby \& Fahey 1995; Wardhani et al. 1993; Hafez 2000). Hasil survei eksistensi IB di wilayah sentra bibit menunjukkan bahwa perlu dilakukan perbaikan terhadap infrastruktur IB; sedangkan di wilayah pengembangan dibutuhkan perbaikan teknis dalam pelaksanaan IB (Affandhy et al. 2005). Perbaikan tatalaksana perkawinan melalui pemendekan waktu thawing dan waktu IB yang tepat dapat meningkatkan nilai S/C $<1,75$ dan persentase kebuntingan $>60 \%$ (Affandhy et al. 2006). Dengan demikian perlu melaksanakan penelitian menggunakan bahan tambahan pakan alternatif (suplemen leguminosa atau limbah pabrik atau produksi pertanian), dengan harapan akan terjadi peningkatan produktivitas induk.

\section{Produktivitas induk}

Tabel 2. Performa produksi dan reproduksi sapi induk laktasi pada tahun 2010, 2011, 2012 dan 2013

\begin{tabular}{lcccc}
\hline \multirow{2}{*}{ Parameter } & \multicolumn{4}{c}{ Tahun } \\
\cline { 2 - 5 } & 2010 & 2011 & 2012 & 2013 \\
\hline Bobot badan calving (kg) & $300,7 \pm 42,7$ & $298,3 \pm 37,3$ & $346,8 \pm 51,0$ & $354,1 \pm 50,7$ \\
Bobot badan sapih (kg) & $329,4 \pm 41,1$ & $322,8 \pm 43,9$ & $303,4 \pm 50,2$ & $313,0 \pm 43,1$ \\
PBBH (kg/hari) & $-0,05 \pm 0,03$ & $-0,03 \pm 0,03$ & $-0,22 \pm 0,21$ & $-0,13 \pm 0,17$ \\
SKT awal & 3,1 & 3,2 & 3,3 & 3,2 \\
SKT akhir & 2,5 & 2,7 & 2,6 & 2,7 \\
Pertambahan SKT ${ }^{*}$ & $-0,6$ & $-0,5$ & $-0,3$ & $-0,5$ \\
Anestrus post partus & $156,1 \pm 83,2$ & $168,7 \pm 88,1$ & $140,3 \pm 68,9$ & $153,7 \pm 70,1$ \\
(hari) & $1,6 \pm 0,7$ & $1,29 \pm 0,63$ & $1,36 \pm 0,5$ & $1,4 \pm 0,6$ \\
Service per conception & 52,9 & 56,8 & 63,6 & 68,2 \\
Conception rate (\%) & $532,8 \pm 174,0$ & $533,5 \pm 178,3$ & $486,0 \pm 69,7$ & - \\
Calving interval (hari) & & & & \\
\hline
\end{tabular}

SKT= skor kondisi tubuh skala 1-5

Performans produksi dan reproduksi sapi-sapi induk menunjukkan bahwa PBBH sapi induk laktasi pada tahun 2010, 2011, 2012 dan 2013 mengalami penurunan masingmasing adalah $-0,05 \pm 0,03 \mathrm{~kg} / \mathrm{hari},-0,03 \pm 0,03 \mathrm{~kg} / \mathrm{hari},-0,22 \pm 0,21 \mathrm{~kg} / \mathrm{hari}$ dan $-0,13 \pm 0,17$ 
kg/hari, demikian juga SKT sapi induk laktasi penurunan hingga 19,35\% (tahun 2010) dan 15,63\% (tahun 2011 dan 2012); tetapi pada tahun 2013 terjadi penurunan SKT hingga -5 (Tabel 2), sehingga nilai APP dan S/C pada 2013 lebih besar dibandingkan dengan tahun sebelumnya (Tabel 2). APP pada tahun 2013 menjadi paling tinggi dibandingkan dengan tahun 2012, 2011 dan 2010. Tingginya APP pada tahun 2013 akibat waktu penyapihan pada tahun tahun 2013 lebih panjang daripada tahun 2010, 2011 dan 2012 (Tabel 1); sehingga menyebabkan APP sapi-sapi laktasi menunjukkan nilai tinggi yang akan berpengaruh terhadap S/C dan CR dan berdampak terhadap jarak beranak (Tabel 2). Perlakuan pembatasan menyusu dan suplementasi pada sapi induk setelah beranak berpengaruh nyata terhadap APP, DO dan calving interval, seperti pendapat Westhuizen et al. (2001) yang menyatakan bahwa penyapihan pedet yang lebih awal akan mempercepat kembalinya kondisi badan induk dan kembalinya sekresi hormon yang mendukung perkembangan ovarium yang akan memperpendek APP. Penyusuan akan merangsang sekresi prolaktin (Luteotropic Hormone) oleh kelenjar susu; kondisi prolaktin yang tinggi menyebabkan tingkat progesteron meningkat sehingga estrogen menjadi rendah yang akhirnya berpengaruh terhadap aktualisasi estrus (Hadisutatnto 2008). Terlambatnya estrus menyebabkan periode anoestrus post partus semakin panjang (Markey et al. 2000). Penyapihan pedet sapi potong di peternakan rakyat umumnya dilakukan antara umur 4-12 bulan (Affandhy et al. 1998; Arifin \& Rianto 2001; Affandhy \& Pamungkas 2007). Pedet-pedet tersebut berkumpul dengan induknya selama 24 jam (Yusran \& Affandhy 1996), sehingga berpengaruh terhadap aktivitas ovarium pasca beranak maupun timbulnya anestrus post partus (APP) (Komarudin-Ma'sum et al. 2000; Affandhy et al. 2001; Hafez 2000; Margerison et al. 2002). Akibat perlakuan penyapihan dini juga berpengaruh terhadap S/C lebih rendah (Tabel 2).

\section{Ragam pakan induk di Malang}

Jenis dan konsumsumsi pakan segar pada sapi induk laktasi di wilayah Malang pada tahun 2010, 2011, 2013 dan 2013 disajikan pada Tabel 3. Pemberian pakan lebih banyak rumput gajah dan daun legum terutama pada tahun 2010 dikarenakan di wilayah Malang bagian selatan tampaknya curah hujan lebih tinggi (Gambar 1) dan banyak ditumbuhi rumput gajah pohon gamal sehingga persedian pakan cukup (Gambar 2), akan tetapi pada wilayah penelitian waktu penyapihan pedet lebih lama (Ratnawati et al. 2019), sehingga jumlah pakan yang diberikan lebih banyak namun pedet masih menyusui sehingga kebutuhan pakan kurang sehingga APP lebih panjang (Tabel 2).

Pada masa laktasi awal, kebutuhan akan energi sangat diperlukan selain untuk produksi air susu tetapi juga untuk mengembalikan fungsi normal reproduksi. Jika intake energi rendah atau tidak sesuai dengan kebutuhan maka akan terjadi keseimbangan energi negatif. Keseimbangan energi yang negatif akan berpengaruh pada turunnya berat badan, menjadi kurus, produksi susu turun, estrusnya tidak jelas/silent heat (Prihatno 2004). Masa laktasi sapi induk akan mempengaruhi kebutuhan nutrisi, sehingga periode penyusuan pedet akan berdampak terhadap konsumsi pakan ternak (NRC 1984). Demikian pula fluktuasi pakan selama setahun. 
Tabel 3. Jenis dan konsumsi pakan segar pada sapi induk laktasi pada tahun 2010, 2011, 2012 dan 2013

\begin{tabular}{lcccccccc}
\hline \hline & \multicolumn{7}{c}{ Tahun Pengamatan } \\
\cline { 2 - 9 } Jenis pakan & \multicolumn{2}{c}{2010} & \multicolumn{2}{c}{2011} & \multicolumn{2}{c}{2012} & \multicolumn{2}{c}{$2013^{*}$} \\
\cline { 2 - 9 } & $\mathrm{kg}$ & $\%$ & $\mathrm{~kg}$ & $\%$ & $\mathrm{~kg}$ & $\%$ & $\mathrm{~kg}$ & $\%$ \\
\hline Jerami padi & $7,2 \pm 9,3$ & 22,1 & $13,4 \pm 67,4$ & 50,0 & $10,7 \pm 6,7$ & 46,2 & $18,5 \pm 5,9$ & 61,5 \\
Rumput gajah & $13,6 \pm 9,0$ & 43,1 & $6,1 \pm 2,9$ & 6,2 & $8,4 \pm 6,7$ & 15,9 & $8,0 \pm 6,3$ & 26,0 \\
Rumput alam & $2,3 \pm 4,5$ & 8,3 & $2,11 \pm 4,4$ & 7,3 & $3,2 \pm 4$ & 6,7 & 0 & 0 \\
Daun gamal & $7,9 \pm 5,4$ & 26,4 & $1,9 \pm 3,2$ & 6,5 & $3,7 \pm 2,5$ & 15,9 & $3,1 \pm 1,7$ & 10,2 \\
Jerami jagung & 0 & 0 & $3,4 \pm 7,3$ & 11,8 & $1,2 \pm 2$ & 3,4 & 0 & 0 \\
Dedak padi/ & $0,6 \pm 0,2$ & 0,2 & $0,3 \pm 0,4$ & 0,9 & $0,4 \pm 0,5$ & 1,7 & $0,5 \pm 0,5$ & 1,6 \\
konsentrat & & & & & & & & \\
\hline
\end{tabular}

*Jerami basah dan kering; Keterangan: * pertengahan 2013, ** gabungan dengan rumput gajah, gabung dengan jerami padi

\section{KESIMPULAN}

Disimpulkan bahwa performa produksi dan reproduksi sapi potong induk di lahan marginal Kec. Bantur Kab. Malang dengan menghasilkan pedet sejumlah pedet 61 ekor (61\%) pada tahun 2010; 69 ekor (69\%) pada tahun 2011 dan 42 ekor (42\%) pada pada tahun 2012; namun pada tahun 2013 jumlah kelahiran pedet terjadi kenaikan menjadi 62 ekor (61\%). Disarankan perlu menggunakan bahan tambahan pakan alternatif (suplemen leguminosa atau limbah pabrik atau produksi pertanian) pada induk untuk mempertahankan skor kondisi tubuh, disertai pengelolaan manajemen yang benar agar terjadi peningkatan produktivitas dan pendampatan petani.

\section{UCAPAN TERIMA KASIH}

Terima kasih kami sampaikan kepada ACIAR untuk pendanaan ini penelitian dan semua tim proyek ACIAR LPS/2008/038 (Dennis Poppi, Dianne Mayberry dan Frans Cowley), serta petani desa, untuk semua tim kerja sama antara ACIAR, Australia dan Lolitsapi (Indonesia).

\section{DAFTAR PUSTAKA}

Affandhy L, Yusran MA, Mariyono. 1998. Effect of weaning age on post-partum anoestrous of Peranakan Ongole cows under smallholder framers in East Java. Bull Anim Sci. Supplement edition 1998:312-315.

Affandhy L, Yusran MA, Winugroho M. 2001. Pengaruh frekuensi pemisahan pedet pra-sapih terhadap tampilan reproduktivitas induk dan pertumbuhan pedet sapi Peranakan Ongole. Dalam: Haryanto B, Setiadi B, Sinurat AP, Mathius IW, Situmorang P, Nurhayati, Ashari, Abubakar, Murdiati TB, Hastiono S, Hardjoutomo S, Adjid RMA, Priadi A, penyunting. Prosiding Seminar Nasional Teknologi Peternakan dan Veteriner. Bogor (Indonesia): Pusat Penelitian dan Pengembangan Peternakan. hlm. 147-154. 
Affandhy L, Pamungkas D, Hartati, Prihandini PW, Situmorang P, Susilowati T. 2005. Peningkatan produktivitas sapi potong melalui efisiensi reproduksi. Laporan Penelitian. Pasuruan (Indonesia): Loka Penelitian Sapi Potong.

Affandhy L, Yusran MA, Anggraeny YN, Pamungkas D. 2006. Kinerja produksi dan umur pubertas pedet hasil kawin silang sapi PO, Simmental dan Limousin dalam usaha peternakan rakyat. Dalam: Mathius IW, Sendow I, Nurhayati, Murdiati TB, Thalib A, Beriajaya, Suparyanto A, Prasetyo LH, Darmono, Wina E, penyunting. Prosiding Seminar Nasional Teknologi Peternakan dan Veteriner. Bogor (Indonesia): Pusat Penelitian dan Pengembangan Peternakan. hlm. 176-182.

Affandhy L, Pamungkas D, Prihandini PW, Wijono DB, Pratiwi WC, Ratnawati D. 2007. Peningkatan produktivitas sapi potong melalui perbaikan efisiensi reproduksi. Laporan Penelitian. Pasuruan (Indonesia): Loka Penelitian Sapi Potong.

Affandhy L, Pamungkas D. 2007. Hasil inseminasi buatan sapi potong di wilayah agroekosistem kering dan basah Jawa Tengah. Prosiding Seminar Nasional. Dalam Rangka Dies Natalis Ke-38 Fakultas Peternakan Universitas Gadjah Mada. Yogyakarta (Indonesia): Universitas Gadjah Mada. hlm. 23-29.

Affandhy L, Rasyid A, Krishna NH. 2010. Pengaruh pembatasan menyusu pedet sapi potong terhadap kinerja reproduksi induk pasca beranak: Studi kasus pada sapi induk PO di usaha ternak rakyat Kabupaten Pati Jawa Tengah. Dalam: Prasetyo LH, Natalia L, Iskandar S, Puastuti W, Herawati T, Nurhayati, Anggraeni A, Damayanti R, Darmayanti NLPI, Estuningsih SE, penyunting. Prosiding Seminar Nasional Teknologi Peternakan dan Veteriner. Bogor (Indonesia): Pusat Penelitian dan Pengembangan Peternakan. hlm. 40-46.

Affandhy L, Dikman DM, Wahyudi T, Cahyono DB, Mayberry DE, Fordyce G, Poppi DP. 2011. Reproductive performance of ongole cows in Indonesian villages. Proceeding of Northern Australia Beef Research Update Conference. Holday Inn Esplanade. Darwin (Australia): North Australia Beff Researh Council. hlm. 111.

Affandhy L, Ratnawati D, Dikman DM. 2019. Pengaruh waktu perkawinan pasca beranak terhadap performa produktivitas sapi induk pada kondisi peternakan rakyat. JIIP. 29.

Arifin M, Rianto E. 2001. Profile produktivitas sapi Peranakan Ongole pada peternakan rakyat: Studi kasus di Kabupaten Grobogan, Jawa Tengah. J Trop Anim Dev. Special Edition 2001:118-123.

Boothby D, Fahey G. 1995. A practical guide artificial breeding of cattle. Agmedia, East Melbourne Vic 3002. p. 127.

Dikman DM, Affandhy L, Wahyudi T, Mayberry DE, Fordyce G, Poppi DP. 2011. Performans reproduksi sapi PO dengan skor kondisi tubuh yang berbeda pada kondisi peternakan rakyat di Kabupaten Malang. Dalam: Prasetyo LH, Damayanti R, Iskandar S, Herawati T, Priyanto D, Puastuti W, Anggraeni A, Tarigan S, Wardhana AH, Darmayanti NLPI, penyunting. Prosiding Seminar Nasional Teknologi Peternakan dan Veteriner. Bogor (Indonesia): Pusat Penelitian dan Pengembangan Peternakan. hlm. 7579.

Hafez ESE. 2000. Reproduction in farm animals. 7th ed. Reproductive Health Center. Kiawah Island, South Carolina (USA): IVF Andrology Laboratory. p. 509.

Hadisutanto B. 2008. http://politani.blogspot.com/ [Internet]. [cited 09 September 2018]. Avaliable from: http://politani.blogspot.com/. 
Komarudin-Ma'sum, Teleni E, Winugroho M, Affandhy L. 2000. Ovarian response in Indonesian Peranakan Ongole cows to a roughage diet supplemented with a mix of shrub legume leaves. Asian-Aust J Anim Sci. 13:187.

Margerison JK, Preston TR, Philipst CJC. 2002. Restricted suckling of tropical diary cows by their calf or their cows calves. J Anim Sci. 80:1663-1670.

Talib C, Noor YG. 2008. Penyediaan daging sapi nasional dalam ketahanan pangan Indonesia. Dalam: Sani Y, Martindah E, Nurhayati, Puastuti W, Sartika T, Parede L, Anggraeni A, Natalia L, penyunting. Prosiding Seminar Nasional Teknologi Peternakan dan Veteriner. Bogor (Indonesia): Pusat Penelitian dan Pengembangan Peternakan. hlm. 44-51.

NRC. 1984. Nutrients requirements of beef cattle. 6th ed. Washington DC (USA): National Academy Press. p. 47-61

Prihatno SA. 2004. Infertilitas dan sterilitas: Hand out infertilitas dan Sterilitas. Yogyakarta (Indonesia): Fakultas Kedokteran Hewan, Universitas Gadjah Mada.

Sumaryadi MY. 2008. Orasi Ilmiah Guru Besar Mas Yedi Sumaryadi [Internet]. [Cited 29 Oktober 2008]. Avalaible from: http://kbi.gemari.or.id.

Wardhani MK, Musofie A, Umiyasih U, Affandhy L, Yusran MA, Wijono DB. 1993. Pengaruh perbaikan gizi terhadap kemampuan reproduksi sapi Madura. Dalam: Komarudin-Ma'sum et al, editors. Pertemuan Ilmiah Hasil Penelitian dan Pengembangan Sapi Madura Sub Balitnak Grati. hlm. 164-167.

Westhuizen RR, Schoeman SJ, Jordan GF, Van Wyk JB. 2001. Genetic parameters for reaproductive traits in a beef catlle herd estimated using Multitraits Analysis [Internet]. [cited 24 September 2009]. Available from: http://www.sasas.co.za/sajas.html 